\title{
Identifikasi Faktor-Faktor yang Mempengaruhi Sales Performance pada Perusahaan Media Periklanan : Studi Empirik pada Tenaga Penjual di RCTI
}

\author{
Endhar Priyo Utomo* \\ Magister Ilmu Komunikasi, Universitas Diponegoro, Indonesia
}

\begin{abstract}
This research was conducted because of the gap from the results of previous research (research gap) regarding the level of sales experience can affect sales performance and empirically examine the factors that influence sales performance such as salesperson skills, sales interaction quality and effectiveness of sales activities. The purpose of this study is to build a conceptual model to describe and provide answers to the gap between sales experience variables on sales performance, and empirically examine the factors that influence Sales performance. This study uses a population of all RCTI's marketing department workforce. This study uses the Judgment Sampling method of respondents which was determined as a study sample of 120 people. The analysis technique used in interpreting and analyzing research data is the Structural Equation Model (SEM) technique from the AMOS 20 software package. The results of hypothesis testing proved that the sales experience factor, salesperson skill, sales interaction quality and effectiveness of sales activities had a positive effect on significant sales performance. The research model can be accepted, from the results calculated by the suitability index where the chi-square value is 200,633 , probability value 0,027 , TLI value 0,974 , CFI value 0,977 , CMIN / DF 1,223 and RMSEA 0,043 all of which meet the requirements even though the GFI value is 0,880 and AGFI 0,846 can marginal accepted.
\end{abstract}

JEL : M30

Keywords: sales experience, sales interaction quality, salesperson skill, sales performance.

\section{PENDAHULUAN}

Era globalisasi saat ini makin berkembang dengan adanya teknologi yang modern dan canggih. Hal ini menyebabkan adanya persaingan antar industri, sehingga komunikasi sangat diperlukan. Terutama komunikasi melalui periklanan yang dijadikan sebagai alat bantu meningkatkan daya saing untuk menunjang keberhasilan kinerja pemasaran (marketing). Seorang tenaga penjual merupakan penunjang dalam perusahaan untuk mendapatkan pelanggan (Terho, Haas, Eggert, \& Ulaga, 2012). Beberapa para ahli berpendapat kondisi kinerja yang baik akan tercipta apabila perusahaan memiliki strategi yang dapat menciptakan tenaga penjualan yang handal.

Tenaga penjual yang mampu meyakinkan pembeli, akan menguntungkan penjualan perusahaan. Karena itu, seorang tenaga penjualan harus memiliki keterampilan dan pengetahuan,

\footnotetext{
${ }^{*}$ E-mail : endhar.priyo @gmail.com

Received : 04-03-2019, Accepted : 18-03-2019, Published : 29-04-2019

P-ISSN : 2087 - 9954, E-ISSN : 2550 - 0066. DOI : http://dx.doi.org/10.26418/jebik.v8vi1.31549
} 
seperti kemampuan mengumpulkan informasi tentang pelanggan, menganalisis/ memahami masalah pelanggan, dan menyesuaikan penawaran yang telah disesuaikan dengan kebutuhan pelanggan (Abed \& Haghighi, 2009). Penelitian (Schmitz, 2012; SchwepkerJr. \& Good, 2010), menyatakan bahwa tenaga penjual memiliki peran penting dalam meningkatkan kinerja penjualan. Karena, tenaga penjual sebagai alat penggerak untuk komunikasi secara langsung dengan pelanggan, memberikan informasi suatu produk untuk menyakinkan pelanggan sehingga tertarik dan keluar keinginan untuk membeli produk (Rocco \& Bush, 2016; Zoltners, Sinha, \& Lorimer, 2013).

Tujuan penelitian adalah membangun model konseptual untuk menggambarkan dan memberikan jawaban pada kesenjangan antara variabel sales experience terhadap sales performance, serta menguji secara empiris faktor-faktor yang mempengaruhi sales performance.

\section{KAJIAN LITERATUR}

Menurut Verbeke, Dietz, \& Verwaal (2011), kinerja penjualan digunakan sebagai bahan dalam evaluasi hasil kontribusi penjualan tenaga penjual dalam mencapai tujuan perusahaan. Kinerja adalah perilaku dari tenaga penjual, dengan berbagai strategi sebagai bentuk tanggung jawab dari pekerjaannya. Strategi yang digunakan tenaga penjual menunjukan perilaku tenaga penjualan dan besar hasil yang telah didapatkan dari usaha penjualannya. Aspek pengalaman dan keahlian tenaga penjual sebagai faktor pendorong dari kinerja penjualan, yang memberikan pengaruh positif terhadap peningkatan kinerja penjualan. Keahlian dalam aktivitas/ kegiatan penjualan menjadi kebutuhan yang harus dimiliki seorang tenaga penjual, karena keahlian merupakan persoalan penting untuk menghadapi konsumen dan perusahaan.

Menurut Zhang, Baxter, \& S.Glynn (2013), pengalaman seorang tenaga penjual dapat memberikan pengaruh positif terhadap peningkatan kemampuan menjual, yang nantinya kemampuan tenaga penjual memiliki pengaruh yang positif terhadap kinerja penjualan. Zhang et al. (2013), melakukan penelitian mengenai pengaruh sales experience. Hasilnya bahwa sales experience berpengaruh positif terhadap sales performance. Penelitian Cicala, Smith, \& Bush (2012), menyimpulkan bahwa pengalaman menjual menjadi tolak ukur yang menandakan seorang tenaga penjual berkompenten dalam mendapatkan pelanggan. Pengalaman menjual dijadikan sebagai pembelajaran positif, untuk meningkatkan prestasi tenaga penjual mewujudkan kinerja perusahaan. Hasilnya bahwa sales experience berpengaruh terhadap sales performance.

Berdasarkan hasil penelitian Lin, Hsu, \& Yeh (2015) dan Valenzuela, Torres, Hidalgo, \& Farías (2014), disimpulkan bahwa sales experience tidak berpengaruh terhadap sales performance. Hasil penelitian menunjukan pengalaman penjualan yang melebihi rata-rata tidak signifikan terhadap kinerja penjualan. Kemampuan tenaga penjual sebagai pondasi dalam mewujudkan kinerja penjualan yang tinggi.

Keberhasilalan suatu perusahan tergantung dari faktor internal perusahaan. Faktor internal dipengaruhi dari kualitas tenaga penjual dan kinerja manajemen penjualan yang menjadi prioritas perusahaan. Keberhasilan kinerja perusahaan diukur dari total jumlah penjualan, porsi target pasar meningkat, cost, kontribusi profitabilitas perusahaan, serta kepuasaan pelanggan (F.L.Chung, 2011). 
Peningkatan kinerja penjualan sangat dipengaruhi dari kinerja tenaga penjual. Oleh karena hal tersebut, beberapa perihal yang perlu diperhatikan dalam pengelolaan tenaga penjual antara lain: pelatihan untuk mengelola kemampuan tenaga penjual dalam mengelola performa kinerja yang dari tenaga penjual. Kegiatan/aktivitas penjualan sangat efektif apabila tenaga penjual memiliki kemampuan dan pengalaman yang tinggi. Belajar dari pengalaman adalah salah satu hal kunci sukses tenaga penjual dalam meningkatkan kinerja (A.Vlachos, Theotokis, \& G.Panagopoulos, 2010).

Berdasarkan latar belakang masalah dengan adanya research gap mengenai tingkat sales experience dapat mempengaruhi sales performance yaitu terdapat perbedaan hasil penelitian Valenzuela et al. (2014) dengan penelitian sebelumnya yang dilakukan Singh \& Das (2013). Hasil penelitian dari Valenzuela et al. (2014) bahwa pengalaman penjualan yang melebihi ratarata tidak signifikan dalam peningkatan kinerja penjualan. Sedangkan penelitian sebelumnya yang dilakukan oleh Singh \& Das (2013) menemukan bahwa pengalaman signifikan terhadap peningkatan pertumbuhan kinerja dari waktu ke waktu. Untuk mengatasi permasalahan tersebut, penelitian ini mencoba untuk menyelesaikan dengan pendekatan teori yang mendasari penelitian ini yakni menggunakan teori Resource-Based View sebagai landasan dari pengembangan teori yang melihat kemampuan sumberdaya internal perusahaan dengan dalam mengeksploitasi sumber daya internal. Sumberdaya internal perusahaan yang terdiri dari semua asset kapabilitas, kompetensi, proses organisasi, informasi dan pengetahuan (Hunt \& Morgan, 2005).

Perusahaan selalu menjadikan tenaga penjual sebagai penghubung antara perusahaan dengan pelanggan. Karena, tenaga penjual adalah salah satu media perantara untuk produk/ jasa yang dimiliki perusahaan dapat sampai ke konsumen. Tenaga penjual menjadi sumber utama dalam meningkatkan pendapatan penjualan perusahaan. Melalui tenaga penjual, perusahaan dapat mengetahui perkembangan pasar secara real-time, serta dapat mengidentifikasi tren baru dan melakukan peramalan bisnis. Penelitian dari Terawatanavong, J.Whitwell, E.Widing, \& O'Cass (2011), mengembangkan pemahaman yang lebih luas mengenai kemampuan tenaga penjual, yakni upaya untuk memenuhi peningkatan pelanggan.

Salah satu hal, yang harus dilakukan tenaga penjual adalah menciptakan interaksi hubungan yang baik di lingkungan bisnis, yaitu dengan mengetahui kebutuhan pelanggan dan melayani pelanggan sebaik-baiknya. Dengan begitu kerjasama akan terjalin dalam jangka panjang (Rakesh Singh \& Venugopal, 2015). Kemampuan lain yang harus dimiliki tenaga penjual adalah kemampuan untuk beradaptasi, hal ini merupakan salah satu strategi penjualan yang berguna untuk meningkatkan penciptaan nilai pelanggan yang lebih tinggi (Voola, Casimir, Carlson, \& Agnihotri, 2012).

Sales experience merupakan faktor penting untuk mempengaruhi efektivitas kegiatan tenaga penjual. Penelitian dari Zallocco, Pullins, \& Mallin (2009), menemukan adanya implikasi penting bagi bisnis produk/ jasa, dimana kegiatan tenaga penjual yang menjadi faktor utama strategi pemasaran produk/jasa. Terlihat dengan adanya kontribusi signifikan terhadap pemahaman bagimana bisnis jasa/produk dapat berhasil, dan meningkatnya kinerja bisnis. Faktor-faktor yang diduga mempengaruhi adalah effectiveness of sales activities (efektivitas kegiatan tenaga penjual).

Menurut Cicala et al. (2012), belajar dari pengalaman membuat tenaga penjual terlatih dalam menggunakan waktu seefektif mungkin, saat melakukan kegitan penjualan. Tenaga 
penjual yang telah berpengalaman akan selalu memberikan pemahaman yang mendalam kepada pelanggan, dan pengalaman yang dimiliki tenaga penjual akan membuat mereka lebih mengerti atas strategi penjualan mana yang layak untuk diaplikasikan pada kegiatan penjualan.Oleh Karena itu, penulis mengajukan hipotesis sebagai berikut:

H1: Semakin tinggi sales experience yang dimiliki tenaga penjual, maka semakin tinggi effectiveness of sales activities.

Pada umumnya sales experience diasumsikan lebih dapat mengidentifikasi kebutuhan pelanggannya, karena selalu dapat membentuk hubungan berkualitas satu sama lain dan saling bertukar informasi (Jaramillo \& Grisaffe, 2009). Selain itu, tenaga penjual yang berpengalaman cenderung sudah memiliki basis pelanggan yang besar. Diartikan secara logis, pelanggan tersebut dapat menjalain kerjasama bisnis berulang yang lebih potensial. Untuk lebih lanjut, secara tidak sengaja tenaga penjual membuat pelanggan akan mereferensikan penjual kembali. Hal seperti ini sering terjadi pada direct selling (penjualan langsung), karena dengan adanya interaksi secara langsung basis pelanggan akan bertahap bertambah menjadi lebih besar di sepanjang waktu.

Pengalaman yang dimiliki tenaga penjual memberikan manfaat dalam menciptakan hubungan kegiatan penjualan, yakni dengan pengalaman, secara tidak langsung pelanggan akan menilai tenaga penjual yang berpengalaman sebagai karyawan yang setia pada perusahaannya. Hal ini dapat membangun serta mempertahankan hubungan jangka panjang dengan pelanggannya. Keuntungan yang didapatkan dalam membangun hubungan jangka panjang adalah efek finansial kumulatif yang tumbuh di sepanjang waktu \{Reicheld, 1996 dalam Jaramillo \& Grisaffe (2009)\}. Berdasarkan penjelasan yang diberikan, maka penulis mengajukan hipotesis sebagai berikut:

H2: Semakin tinggi sales experience (pengalaman penjualan) yang dimiliki tenaga penjual, maka semakin tinggi sales interaction quality tenaga penjual dengan konsumen.

Menurut Zallocco et al. (2009), salesperson skill sangat dibutuhkan dalam kegiatan penjualan. Berdasarkan evaluasi yang telah dilakukan, bahwa pengetahuan dan informasi yang dimiliki tenaga penjual, sangat diperlukan untuk membangun hubungan berkualitas dengan pelanggan. Kemampuan tenaga penjual terlihat saat mereka mampu mempengaruhi pelanggan, yang tentunya akan mempengaruhi performance tenaga penjual. Menurut Altintas, Kurtulmusoglu, Altintas, Kaufmann, \& Alkibay (2017), mengatakan bahwa kemampuan tenaga penjual dalam meyesuaikan diri dengan pelanggan (beradaptasi) dapat memudahkan implementasi hubungan antara tenaga penjual dengan pelanggan. Dapat disimpulkan bahwa keahlihan yang dimiliki tenaga penjual akan menciptakan efektifitas kegiatan penjualan positif dan memberi keuntungan kepada perusahaan dari hasil penjualan yang tinggi.

Pendapat dari Román \& Iacobucci (2010), pencapaian tingkat kinerja penjualan yang tinggi dapat terjadi karena pemilihan dan penerapan pendekatan kepada pelanggan yang telah disesuaikan tenaga penjual, untuk menghadapi berbagai sifat unik pelanggan dari setiap situasi penjualan, dan mampu memberikan solusi yang tepat, dengan begitu tenaga penjual akan menjadi berharga dimata pelanggan. Untuk itu penulis mengajukan hipotesis sebagai berikut:

H3: Semakin tinggi salesperson skill maka semakin tinggi sales interaction quality yang diciptakan tenaga penjual dengan pelanggan. 
Suatu interaksi terjadi karena adanya dua pihak yang aktif, dimana satu sama lain memiliki kemampuan saling mempengaruhi, terlibat dalam pertukaran nilai. Secara garis besar interaksi terjadi pada pertukaran nilai manfaat inti (yaitu produk dan layanan), dan pertukaran informasi. Interaksi tenaga penjual dan pembeli akan memberikan nilai positif bagi perkembangan dan pertumbuhan mitra bisnis perusahaan. Karena, kualitas hubungan yang diciptakan mampu meraih pangsa bisnis yaitu pelanggan (Fu, Richards, Hughes, \& Jones, 2010).

Menurut Yu \& Tung (2013), sales interaction quality (interaksi kualitas hubungan) dapat dicapai oleh tenaga penjual dengan cara menjalin hubungan pemasaran antara tenaga penjual dan pelanggan. Hal ini sangat ditekankan dalam membina hubungan jangka panjang, yang saling menguntungkan dan dapat berkelanjutan untuk jangka panjang. Kualitas hubungan mengandung tiga dimensi yakni: kepercayaan, kepuasan dan komitmen pelanggan. Pada kondisi seperti ini akan meningkatkan sales performance karena hal tersebut adalah bagian terpenting dalam memperkuat hubungan pelanggan dan memperoleh pangsa pasar. Maka, penulis mengajukan hipotesis penelitian sebagai berikut:

H4: Semakin tinggi sales interaction quality, maka semakin tinggi sales performance yang diraih tenaga penjual.

Menurut Zallocco et al. (2009), intensitas efektifitas kegiatan penjualan akan meningkatkan kinerja dari waktu ke waktu dan akan memudahkan tenaga penjual menfaatkan peluang kewirausahaan. Dengan demikian,perusahaan dengan mudah menciptakan keunggulan kompetitif. Dapat ditarik kesimpulan bahwa kualitas dan kelayakan perilaku penjual tertentu mengarah pada efektifitas kegiatan penjualan, akan berpengaruh pada peningkatan kinerja penjualan.

Keuntungan dan peningkatan kinerja penjualan berasal dari efektifitas kegiatan penjualan tenaga penjual, efektifitas dilihat dari kinerja penjualan saat meraih kredibilitas pangsa pasar, serta ditunjukan dari pengembalian investasi laba penjualan (Tajeddini, Elg, \& Trueman, 2013). Sehingga, dapat diusulkan hipotesis untuk penelitian adalah:

H5: Semakin tinggi effectiveness of sales activities tenaga penjual, maka semakin tinggi sales performance yang didapatkan tenaga penjual.

\section{METODA PENELITIAN}

Teknik analisis perhitugan yang digunakan adalah SEM (Structural Equation Model) penentuan jumlah sampel minimum menggunakan sebanyak lima observasi untuk setiap estimated parameter, ukuran sampel yang sesuai dengan alat analisis yaitu berkisar antara 100200 responden (Ferdinand, 2014).

Objek penelitian ini adalah perusahaan jasa periklanan. Perusahaan yang diambil sebagai objek penelitian adalah perusahaan jasa periklanan PT. Rajawali Citra Televisi Indonesia. Metode yang digunakan pada penelitian adalah metode judgment sampling. Jumlah sampel yang digunakan pada penelitian sebanyak 120 kuisioner dari 132 kuesioner yang disebar kepada tenaga penjual. Hal ini untuk mengatasi tingkat respons yang rendah. 


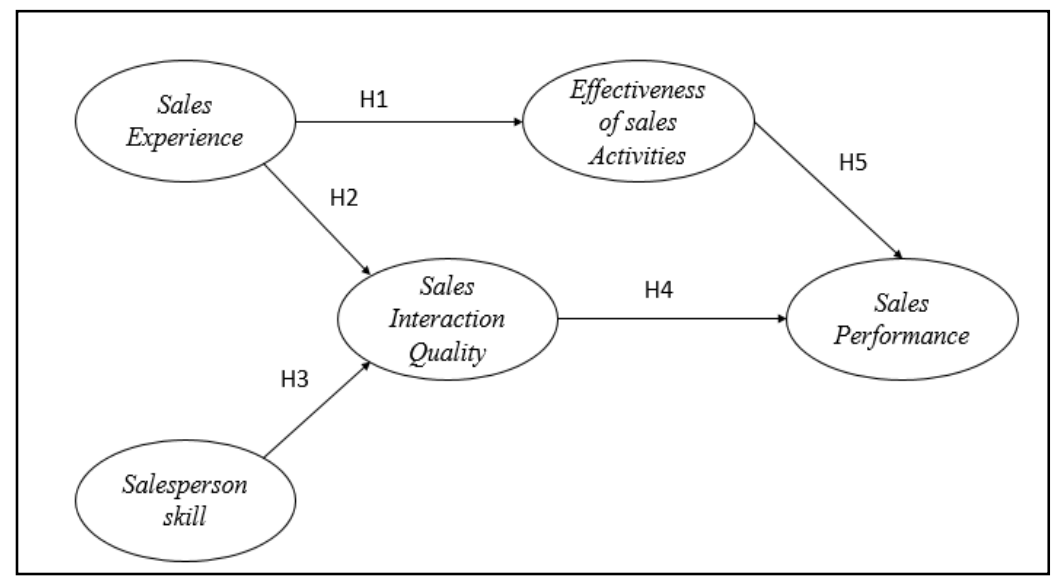

Gambar 1. Model Penelitian

Penelitian ini menggunakan data primer yang dikumpulkan secara langsung, yang selanjutnya dianalisis untuk mencari solusi dari permasalan yang diteliti (Sekaran, 2006). Data primer diperoleh dari penyebaran kuisioner kepada tenaga penjual PT. Rajawali Citra Televisi Indonesia, Jakarta Barat, berupa opini, sikap/karakteristik yang menjadi subyek responden berserta pengalamannya.

\section{HASIL PENELITIAN DAN PEMBAHASAN}

Hasil analisis SEM (structural equation model) dengan full model dilakukan dalam menguji model dan hipotesis. Pengujian model yang dilakukan dengan dua cara yaitu uji kesesuaian model dan uji signifikan kausalitas melalui uji koefisien regresi. Seperti pada gambar dua yang merupakan hasil olahan data untuk analisis SEM.

Tabel 1.

Variabel, Indikator dan Pengukuran

\begin{tabular}{|c|c|c|c|}
\hline VARIABEL & INDIKATOR & PENGUKURAN & REFERENSI \\
\hline \multirow{7}{*}{$\begin{array}{l}\text { Sales } \\
\text { Experience } \\
(\mathrm{SE})\end{array}$} & SE_1 : Berpengalaman & \multirow{7}{*}{$\begin{array}{lr}10 \text { point nilai skala pada } 4 \\
\text { indikator } & \text { yaitu: } \\
\text { Berpengalaman } & \text { menjual } \\
\text { pada beragam } & \text { kelas, } \\
\text { Berpengalaman } & \text { menjual } \\
\text { berbagai jenis } & \text { produk, } \\
\text { Berpengalaman } & \text { dalam } \\
\text { menyesuaikan diri } & \text { dengan } \\
\text { pelanggan, Pengalaman } & \\
\text { berhasil dalam menjual } & \text { malam menjual }\end{array}$} & \multirow{7}{*}{$\begin{array}{lr}\text { Hughes et al. } & \text { (2012), } \\
\text { Jirawuttinaunt } & \text { and } \\
\text { Akkrawimut } & \text { (2012), } \\
\text { Abdolvand } & \text { and } \\
\text { Farzaneh (2013) } & \end{array}$} \\
\hline & pada beragam & & \\
\hline & kelas & & \\
\hline & SE_2 : Berpengalaman & & \\
\hline & $\begin{array}{l}\text { menjual berbagai jenis } \\
\text { produk }\end{array}$ & & \\
\hline & $\begin{array}{l}\text { SE_3 : Berpengalaman } \\
\text { dalam menyesuaikan diri } \\
\text { dengan pelanggan }\end{array}$ & & \\
\hline & $\begin{array}{l}\text { SE_4 : Pengalaman } \\
\text { berhasil dalam menjual } \\
\text { dalam menjual }\end{array}$ & & \\
\hline
\end{tabular}




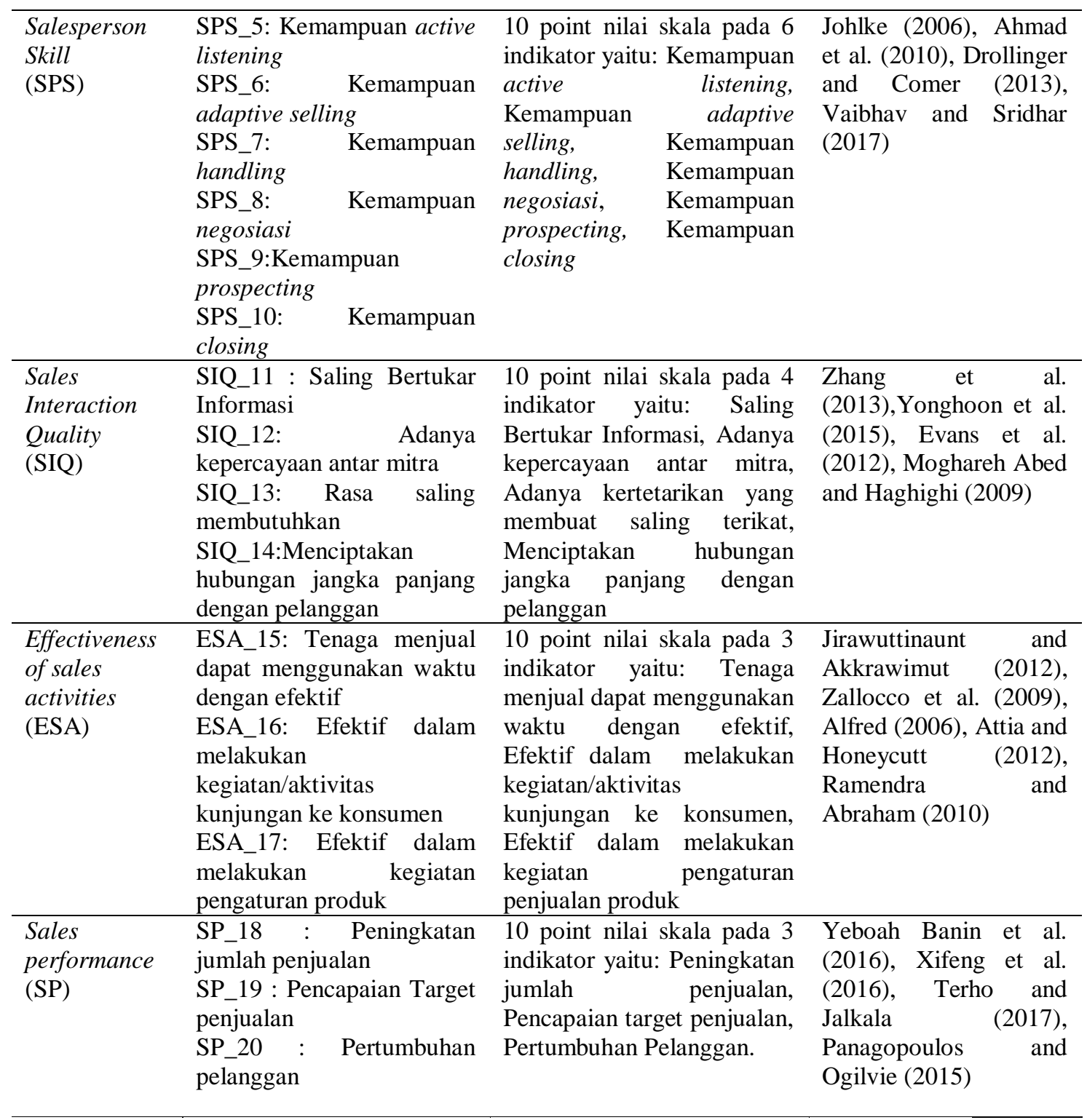

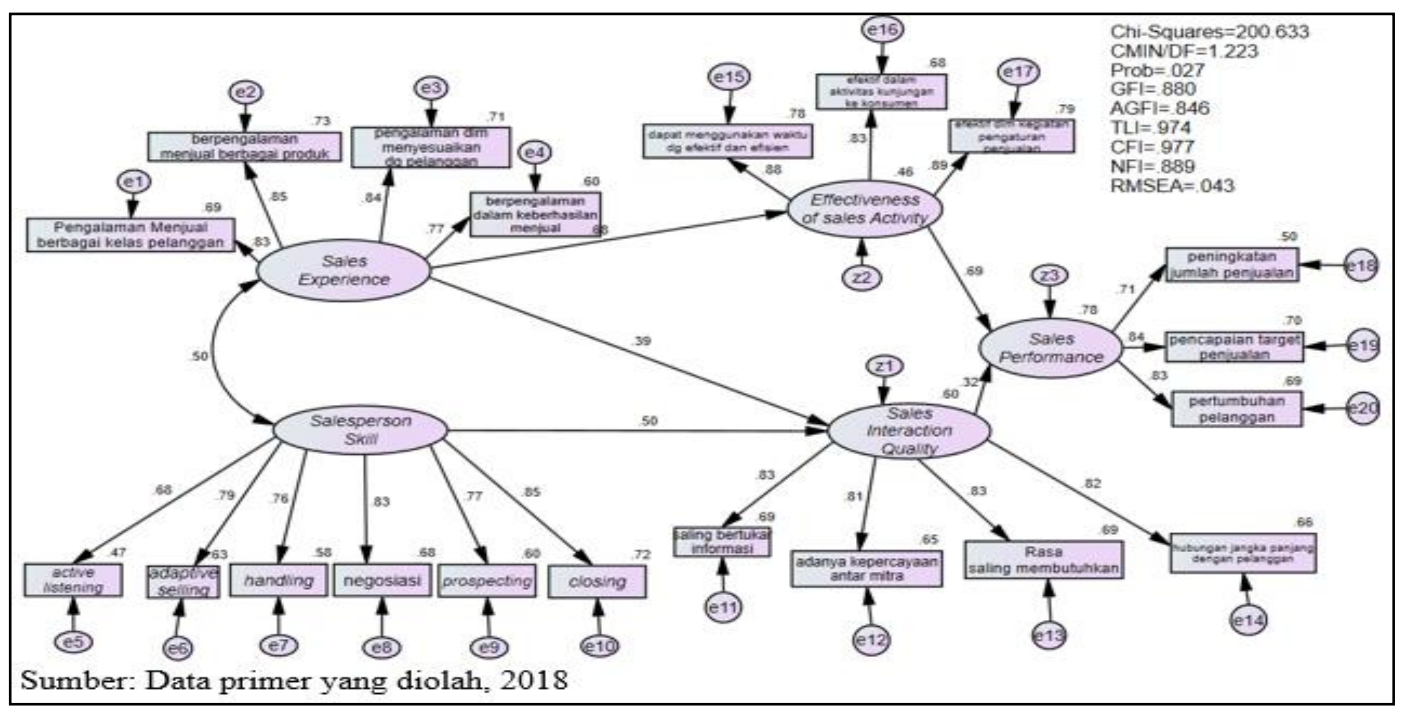

Gambar 2. Hasil Uji Structural Equation Model (Standardized) 
Hasil tersebut menunjukan hasil perhitungan yang sudah sesuai dengan kriteria layak full model. Seperti yang ada pada Tabel 2. Hasil analisis SEM untuk model pengujian hubungan sebab-akibat antara variabel, yang mempengaruhi dan diperngaruhi dari variabel Sales Experience, Salesperson Skill, Sales Interaction Quality, Effectiveness Of Sales activities, Sales performance, yang sudah memenuhi kriteria Goodness of Fit- Full Model dengan hasil Chi Square $=200.633 ;$ Probability $=0,027 ;$ GFI $=0,880 ;$ AGFI $=0,846 ;$ TLI $=0,974 ; \mathrm{CFI}=0,977 ;$ $\mathrm{NFI}=0,899$; RMSEA $=0,43$, hasil data penelitian ini menunjukan bahwa model penelitian dapat diterima.

Hasil yang diperoleh dari memiliki nilai critical ratio (CR) pada hubungan Sales Experience terhadapEffectiveness of Sales activitiessebesar 7,246 dan Probability 0.000; untuk hubungan antara Sales Experience dengan Sales Interaction Qualitycritical ratio (C.R) sebesar 4,228 dan Probability 0,000; Hubungan antara Salesperson Skill dengan Sales Interaction Quality memiliki C.R sebesar 4,823 dan Probability sebesar 0,000; Hasil analisa untuk hubungan dari Effectiveness of sales activities dengan Sales performance adalah nilai C.R 6,058 dan Probabilitas 0,000: Hubungandari variabel Sales Interaction Quality dengan Variabel Sales performance nilai C.R. sebesar 3,056 dan Probabilitas 0,002.

Tabel 2

Hasil Uji Full Model

\begin{tabular}{cccc}
\hline Kriteria & Cut of Value & Hasil & Evaluasi \\
\hline Chi-Square & $\begin{array}{c}\mathrm{x}^{2} \text { dengan df: 164, p: } \\
5 \% \text { adalah 194,882 }\end{array}$ & 200,663 & Baik \\
\hline Probability & $\geq_{0,05}$ & 0,027 & Baik \\
\hline GFI & $\geq_{0,90}$ & 0,880 & Marginal \\
\hline AGFI & $\geq_{0,90}$ & 0,846 & Marginal \\
\hline TLI & $\geq_{0,95}$ & 0,974 & Baik \\
\hline CFI & $\geq_{0,95}$ & 0,977 & Baik \\
\hline CMIN/DF & $\leq_{2,00}$ & 1,223 & Baik \\
\hline RMSEA & $\leq_{0,80}$ & 0,043 & Baik \\
\hline
\end{tabular}

Hasil pada tabel 3 memiliki angka critical ratio (CR) pada hubungan sales experience dengan effectiveness of sales activities sebesar 7,246 dan probability 0.000; untuk hubungan antara sales experience dengan sales interaction quality, critical ratio (CR) sebesar 4,228 dan probability 0,000 ; hubungan antara salesperson skill dengan sales interaction quality memiliki CR sebesar 4,823 dan probability sebesar 0,000; hasil analisa untuk hubungan dari effectiveness of sales activities dengan sales performance adalah nilai CR 6,058 dan probabilitas 0,000: hubungan dari variabel sales interaction quality dengan variabel sales performance nilai $\mathrm{CR}$ sebesar 3,056 dan probabilitas 0,002. 
Tabel 3

Pengujian Hipotesis

\begin{tabular}{llllllll}
\hline & & Estimate & $\begin{array}{l}\text { Regression } \\
\text { Weight }\end{array}$ & .E. & .R. & & Hasil uji \\
\hline $\begin{array}{l}\text { Sales Experience } \\
\text { Effectiveness of sales Activities }\end{array}$ & 0.769 & 0.677 & .106 & .246 & $* *$ & Diterima \\
\hline $\begin{array}{l}\text { Sales Experience } \rightarrow \\
\text { Interaction Quality }\end{array}$ & Sales & 0.421 & 0.393 & .1 & .228 & $* *$ & Diterima \\
\hline $\begin{array}{l}\text { Salesperson Skill } \rightarrow \\
\text { Interaction Quality }\end{array}$ & Sales & 0.604 & 0.498 & .125 & .823 & $* *$ & Diterima \\
$\begin{array}{l}\text { Effectiveness of sales Activities } \\
\rightarrow \text { Sales performance }\end{array}$ & 0.488 & 0.619 & .081 & .058 & $* *$ & Diterima \\
\hline $\begin{array}{l}\text { Sales Interaction Quality } \\
\text { Sales performance }\end{array}$ & $\rightarrow$ & 0.243 & 0.34 & .079 & .056 & .002 & Diterima \\
\hline
\end{tabular}

Berdasarkan hasil penelitian yang telah dilakukan maka hipotesis pertama dapat diterima. Penelitian ini memiliki kesamaan pada penelitian terdahulu yang telah dilakukan oleh Cicala et al. (2012), yakni belajar dari pengalaman membuat tenaga penjual terlatih dalam menggunakan waktu seefektif mungkin, saat melakukan kegitan penjualan. Berdasarkan penelitian yang telah dilakukan dapat disimpulkan hipotesis kedua dapat diterima. Hasil penelitian ini didukung oleh penelitian sebelumnya dari Ramendra Singh \& Das (2013), menyatakan efek pengalaman yang dimiliki tenaga penjual akan menciptakan hubungan jangka panjang dengan pelanggan.

Berdasarkan hasil penelitian, hipotesis ketiga dapat diterima. Hipotesis ini diperkuat oleh penelitian sebelumnya seperti Altıntas et al. (2017) dan Román \& Iacobucci (2010), yang berpendapat kemampuan tenaga penjual dalam melakukan penjualan terdiri dari beberapa hal seperti, kemampuan tenaga penjual dalaam melakukan pendekatan dengan pelanggan pada tipe kelas pelanggan yang berbeda, dan memiliki kepercayaan diri yang kuat dalam membangun hubungan yang baik dengan pelanggan. Variabel sales interaction quality berpengaruh positif terhadap sales performance. Hipotesis penelitian ini didukung oleh beberapa peneliti sebelumnya yaitu dari Fu et al. (2010), Yu \& Tung (2013) yang menyatakan interaksi penjual dan pembeli akan memberikan dampak perkembangan dan pertumbuhan bisnis perusahaan.

Dengan pengujian hipotesis 5 membuktikan adanya pengaruh variabel effectiveness of sales activities terhadap sales performance, membuat hipotesis kelima dapat diterima. Hal tersebut juga didukung oleh peneliti sebelumnya Zallocco et al. (2009) dan Tajeddini et al. (2013) yang menyatakan keuntungan kinerja suatu perusahaan berasal dari efisiensi dan efektifitas kegiatan tenaga penjualan, dilihat dari pengembalian investasi laba penjualan. 


\section{SIMPULAN}

Penelitian ini disusun sebagai usaha untuk melakukan pengkajian permasalahan pada penelitian. Permasalahan pada penelitian ini yakni perbedaan hasil peneliti terdahulu mengenai pengaruh pengalaman menjual terhadap peningkatan kinerja penjualan. Berdasarkan hasil analisis yang telah dilakukan maka dapat diketahui ada beberapa variabel yang memberikan pengaruh secara langsung maupun tidak langsung pada peningkatan kinerja penjualan perusahaan. Effectiveness of sales activities merupakan variabel yang paling tinggi mempengaruhi kinerja penjualan. Effectiveness of sales activities sangat dipengaruhi oleh sales experience. Pengalaman menjual dalam berbagai kelas, pengalaman menjual berbagai produk, pengalaman menyesuaikan diri dengan pelanggan, dan pengalaman berhasil dalam menjual merupakan point-point penting yang harus dimiliki tenaga penjual untuk memperkuat sales experience dalam kaitan pengaruhnya terhadap effectiveness of sales activities.

Salesperson skill termasuk bagian terpenting yang harus dimiliki seorang tenaga penjual dalam membentuk hubungan yang berkualitas dengan pelanggan. Dengan skill yang mereka miliki, berfmanfaat saat mereka bernegosiasi, mampu memberikan solusi sesuai dengan kebutuhan pelanggan. Hal tersebut yang nantinya akan memperkuat hubungan tenaga penjual dengan pelanggan (sales interaction quality).

Sales interaction quality memiliki pengaruh yang positif terhadap sales performance. Banyak responden yang mengakui bahwa hubungan yang dijalin dengan pelanggan memiliki banyak manfaat bagi pribadi maupun perusahaan. Dimana, tenaga penjual selalu berusaha menerima kritik dan saran dari pelanggan, dan memberikan perhatian pada pelanggan. Hal ini cukup berhasil untuk menumbuhkan sikap saling ketergantungan/ saling membutuhkan. Saling bertukar informasi dengan pelanggan, melakukan diskusi pekerjaan melalui media apapun. Sales interaction quality yang tinggi akan mempengaruhi kinerja penjualan.

Perusahaan harus menyadari bahwa efektifnya kegiatan penjualan didukung dari tingkat pengalaman karyawan yang tinggi, karena dengan begitu kegiatan penjualan menjadi lebih terkonsep. Oleh sebab itu karyawan yang memiliki tingkat pengalaman yang tinggi harus dipertahankan karena akan mempengaruhi kefektifan kegiatan penjualan yang sangat berpengaruh terhadap kinerja penjualan. Perusahaan harus membekali tenaga penjualnya dengan pengetahuan produk secara detail serta mengadakan pelatihan tentang bagaimana menangani pelanggan, dan etika yang baik pada saat bernegosiasi. Para manager hendaknya memantau langsung jika terjadi suatu pemasalahan yang rumit (pada waktu deal or no deal). Jika hal tersebut sudah terbentuk, maka tidak sulit untuk tenaga penjual menjalin hubungan yang berkualitas pada pelanggan.

Keterbatasan yang ada pada penelitian ini dapat dikembangkan lebih lanjut. Adapun keterbatasan yang ada dalam penelitian yakni penelitian ini hanya menggunakan satu obyek perusahaan saja dan hanya menggunakan lima variabel. Maka untuk yang akan datang diharapkan dapat memberikan hal baru untuk penelitian ini misalnya dengan menambah obyek penelitian dan menambah beberapa variabel pada mode, serta hipotesis pada penelitian.

\section{DAFTAR PUSTAKA}

A.Vlachos, P., Theotokis, A., \& G.Panagopoulos, N. (2010). Sales Force Reactions to Corporate 
Social Responsibility: Attributions, Outcomes, and the Mediating Role of Organizational Trust. Elsevier Industrial Marketing Management, 39(7), 1207-1218. https://doi.org/https://doi.org/10.1016/j.indmarman.2010.02.004

Abed, G. M., \& Haghighi, M. (2009). The Effect of Selling Strategies on Sales Performance. $\begin{array}{llll}\text { Business } & \text { Strategy } & \text { Series, } & \text { 266-282. }\end{array}$ https://doi.org/https://doi.org/10.1108/17515630910989169

Altıntas, F., Kurtulmusoglu, F. B., Altintas, M. H., Kaufmann, H.-R., \& Alkibay, S. (2017). The Mediating Effects of Adaptive Selling and Commitment on the Relationship between Management Control and Sales Performance. EuroMed Journal of Business, 12(2), 221240. https://doi.org/https://doi.org/10.1108/EMJB-12-2016-0037

Cicala, J. E., Smith, R. K., \& Bush, A. J. (2012). What Makes Sales Presentations Effective - a Buyer-Seller Perspective. Journal of Business \& Industrial Marketing, 27(2), 78-88. https://doi.org/10.1108/08858621211196958

F.L.Chung, H. (2011). Market Orientation, Guanxi, and Business Peformance. Elsevier Industrial Marketing Management, 40(4), 522-533. https://doi.org/https://doi.org/10.1016/j.indmarman.2010.12.008

Ferdinand, A. (2014). Metode Penelitian Manajemen Pedoman Penelitian untuk Menulis Skripsi, Tesis, dan Disertasi Ilmu Manajemen. BP UNDIP, Semarang.

Fu, F. Q., Richards, K. A., Hughes, D. E., \& Jones, E. (2010). Motivating Salespeople to Sell New Products: The Relative Influence of Attitudes, Subjective Norms, and Self-Efficacy. Journal of Marketing, 74(6), 61-76.

Hunt, S. D., \& Morgan, R. M. (2005). The Resource-Advantage Theory of Competition. In N. K. Malhotra (Ed.), Review of Marketing Research (Review of Marketing Research, Volume 1 (pp. 153-206). Emerald Group Publishing Limited.

Jaramillo, F., \& Grisaffe, D. B. (2009). Does Customer Orientation Impact Objective Sales Performance? Insights from a Longitudinal Model in Direct Selling. Journal of Personal $\begin{array}{llll}\text { Selling } \quad \text { S } & \text { Management, } & \text { 29(2), }\end{array}$ https://doi.org/https://doi.org/10.2753/PSS0885-3134290205

Lin, W.-S., Hsu, J.-W., \& Yeh, M.-Y. (2015). Developing the Capability of Marketing Intelligence: A Subjective Dynamic Capability Study. Benchmarking: An International Journal, 22(7), 1341-1359. https://doi.org/https://doi.org/10.1108/BIJ-12-2013-0117

Rocco, R. A., \& Bush, A. J. (2016). Exploring Buyer-Seller Dyadic Perceptions of Technology and Relationships: Implications for Sales 2.0. Journal of Research in Interactive Marketing, 10(1), 17-32. https://doi.org/10.1108/JRIM-04-2015-0027

Román, S., \& Iacobucci, D. (2010). Antecedents and Consequences of Adaptive Selling Confidence and Behavior: a Dyadic Analysis of Salespeople and Their Customers. Journal of the Academy of Marketing Science, 38(3), 363-382.

Schmitz, C. (2012). Group Influences of Selling Teams on Industrial Salespeople's Cross-Selling Behavior. Journal of the Academy of Marketing Science, 41(1), 55-72.

SchwepkerJr., C. H., \& Good, D. J. (2010). Moral Judgment and its Impact on Business-to- 
Business Sales Performance and Customer Relationships. Journal of Business Ethics, 98(4), 609-625.

Sekaran, U. (2006). Metodologi Penelitian untuk Bisnis (4th ed.). Jakarta: Salemba Empat.

Singh, R., \& Das, G. (2013). The Impact of Job Satisfaction, Adaptive Selling Behaviors and Customer Orientation on Salesperson's Performance: Exploring the Moderating Role of Selling Experience. Journal of Business and Industrial Marketing, 28(7), 554-564. https://doi.org/10.1108/JBIM-04-2011-0121

Singh, R., \& Venugopal, P. (2015). The Impact of Salesperson Customer Orientation on Sales Performance via Mediating Mechanism. Journal of Business and Industrial Marketing, 30(5), 594-607. https://doi.org/10.1108/JBIM-08-2012-0141

Tajeddini, K., Elg, U., \& Trueman, M. (2013). Efficiency and Effectiveness of Small Retailers: The Role of Customer and Entrepreneurial Orientation. Journal of Retailing and Consumer Services, 20(5), 453-462. https://doi.org/https://doi.org/10.1016/j.jretconser.2013.05.004

Terawatanavong, C., J.Whitwell, G., E.Widing, R., \& O'Cass, A. (2011). Technological Turbulence, Supplier Market Orientation, and Buyer Satisfaction. Journal of Business Research, 64(8), 911-918. https://doi.org/https://doi.org/10.1016/j.jbusres.2010.09.003

Terho, H., Haas, A., Eggert, A., \& Ulaga, W. (2012). 'It's Almost Like Taking the Sales Out of Selling'-Towards a Conceptualization of Value-Based Selling in Business Markets. Industrial Marketing Management, 41(1), 174-185. https://doi.org/https://doi.org/10.1016/j.indmarman.2011.11.011

Valenzuela, L., Torres, E., Hidalgo, P., \& Farías, P. (2014). Salesperson CLV Orientation's Effect on Performance. Journal of Business Research, 67(4), 550-557. https://doi.org/https://doi.org/10.1016/j.jbusres.2013.11.012

Verbeke, W., Dietz, B., \& Verwaal, E. (2011). Drivers of Sales Performance: A Contemporary Meta-Analysis. Have Salespeople Become Knowledge Brokers? Journal of the Academy of Marketing Science, 39(3), 407-428. https://doi.org/10.1007/s11747-010-0211-8

Voola, R., Casimir, G., Carlson, J., \& Agnihotri, M. A. (2012). The Effects of Market Orientation, Technological Opportunism, and E-Business Adoption on Performance: A Moderated Mediation Analysis. Australasian Marketing Journal (AMJ), 20(2), 136-146. https://doi.org/https://doi.org/10.1016/j.ausmj.2011.10.001

Yu, T., \& Tung, F. (2013). Investigating Effects of Relationship Marketing Types in Life Insurers in Taiwan. Managing Service Quality: An International Journal, 23(2), 111-130. https://doi.org/https://doi.org/10.1108/09604521311303408

Zallocco, R., Pullins, E. B., \& Mallin, M. L. (2009). A Re-Examination of B2B Sales Performance. Journal of Business \& Industrial Marketing, 24(8), 598-610. https://doi.org/https://doi.org/10.1108/08858620910999466

Zhang, A. L., Baxter, R., \& S.Glynn, M. (2013). How Salespeople Facilitate Buyers' Resource Availability to Enhance Seller Outcomes. Industrial Marketing Management, 42(7), 11211130. https://doi.org/https://doi.org/10.1016/j.indmarman.2013.07.004

Zoltners, A. A., Sinha, P., \& Lorimer, S. E. (2013). Breaking the Sales Force Incentive 
Addiction: A Balanced Approach to Sales Force Effectiveness. Journal of Personal Selling \& Sales Management, 32(2), 171-186. https://doi.org/https://doi.org/10.2753/PSS08853134320201 